\title{
Implementing library strategies and values as a part of the workplace information literacy
}

\author{
Marja Hjelt ${ }^{1}$, Jarmo Saarti \\ 'University of Tampere, Doctoral student, Tampere, Finland \\ hjelt.marja.alstudent.uta.fi \\ ${ }^{2}$ University of Eastern Finland, PhD, Library director, Kuopio, Finland \\ jarmo.saarti@uef.fi
}

\begin{abstract}
The paper investigates how the library understanding of the organizational strategy and values affect the adoption of innovations and new services. The paper is based on research and data collected from the adoption of the e-book in Finnish public libraries. The aim is to find out the factors in the libraries' operating culture that support and prevent the introduction of the ebook. It was noted that in the adaptation of new services management needs to market the strategies and motivate the staff in order to encourage the staff to adopt new innovations.
\end{abstract}

Keywords: e-book, attitudes, library staff, executive board, public libraries, Finland

\section{Introduction}

This paper investigates how the library understanding of organizational strategy and values affect the adoption of innovations and new services. It is based on research and data collected from the adoption of the e-book in Finnish public libraries. The aim is to find out the factors in the libraries' operating culture that support or prevent the introduction of the e-book.

Libraries have a two-way impact on introducing innovations. Primarily, the organization must decide on the introduction of innovation and secondly to motivate the staff to accept it [1]. This study identifies the expectations, values and attitudes of the libraries when implementing e-books and related services into the library's collections and services. The research also clarifies what actions are used for the involvement of the staff.

The role of the staff in adopting innovation is to accept it as part of the library service offering and to ensure its delivery to customers. This study focuses on attitudes and social norms that promote or impede the library staff's adoption of e-books and related services as a part of the library's service concept. The study also examines how the library's actions affect the staff's adoption of e-books. 


\section{Literature Review}

There has been little or no research on information literacy in the adoption of innovations. Instead, learning at the work place as part of the adoption of innovation, attitude building and information literacy has been studied. Research so far has not combined these aspects,-_but has focused only on one of the topics.

The adoption of innovations has been widely researched. The main theories are the Rogers' Diffusion of Innovation theory and the Davis' Technology Acceptance model (TAM). Rogers' [1] theory focuses on an individual's ability to embrace innovation by its perception and suitability according to the individual's experience, values and needs. The key factor for embracing innovation is also the communicability of innovation, that is, how does the community feel about innovation and how is this reflected within the community [1]. Also, Davis's TAM is also approaching the adoption of innovation by its perceived usefulness and ease of use. Experience in the ease of use of the system is characterized by the system usability [2].

The adoption of innovation is dependent on attitudes, and one of the key research studies of attitudes is Erwin's [3]. The knowledge capital, feelings, and behavior of the individual influence the formation of attitudes. The cognitive component is related to the beliefs, assumptions, and attributes that the individual associates with the object of the attitudes. Positive and negative perceptions of the object shape attitudes. Feelings, the Affect component, influence the emergence of positive and negative perceptions. The behavioral component, in turn, refers to previous behavior and experiences. [3].

Research on information literacy in the workplace has also focused on learning in the workplace. Lloyd [4] points out that the analysis should focus on understanding the social relationships and activities that enable the development of information literacy but can also limit it. Information literacy comes from practical actions that consist of what is being said and what is being done $_{2}$ and the relationships between these. According to Lloyd [4], information literacy involves understanding the conversations that affect the creation, dissemination, and operational activity of the information. It also involves understanding how information is edited, accepted, or rejected through social activities. Crawford and Irving [5], basing on the Eraut's learning model, argue that formal learning in the workplace is dependent on the workplace's social relations. According to the model, learning is a combination of past knowledge and experiences in the social context [5]. The ways people are learning in the workplace is important and the reliability of the information obtained through the channels was assessed through their own knowledge and experience [5].

\section{Methodology}

\subsection{Framework}

The study is framed through Roger's Diffusion of Innovation -theory, which is widely used in the innovation research. The starting point is to find out the impact of 
the operating culture on adopting the innovation. In the operational culture, one includes all the organization's formal and informal rules, practices and behaviors model, values, principles and criteria; and it rises within the framework of the intellectual, material and social practices [6]. According to Rogers [1] a key factor in adoption is the compatibility of lifestyles, social system, and standards.

Rogers' theory is general in nature and provides guidelines for research, but it needs to be complemented by more focused theories to identify areas of innovation adoption. One of the key factors in adopting innovation is the compatibility of innovation with the community values, whose formation is influenced by attitudes. The formation of attitudes can be defined by Davis's Technology Acceptance Model, here Aharony [7]. The model has been developed for the adoption of work related information systems into work routines [7] and it is based on the social psychology theory of reasoned action: attitudes and beliefs are related to people's intentions to perform. The key to this model is that attitudes affect our behavior towards innovation. Attitudes are based on the information available to the individual [7].

Work-related information literacy means the ability to find, apply and use information to solve work-related challenges and to employ various suitable data resources at work as Kirton and Barham state [8]. According to Molopyane and Fourie, [8] the American Library Association's Presidential Committee defines the information literate workforce as one that knows how to learn, knows how knowledge is organized, can locate information, and uses information in such a way that others can learn from them.

The adoption of innovation is influenced by the staff's values and attitudes whose background is taught. Information literacy in workplace is also related to learning in the workplace, so Rogers' innovation theory is well suited to the framework of this study.

\subsection{Research Questions}

The study tries to answer how the libraries' operating culture affects the introduction of e-books. Specifically, we are studying the following:

1. Libraries as innovators:

1.1 What are the expectations, values, and attitudes of libraries on the adoption of ebooks and related services?

1.2 Regarding e-books and related services what kinds of activities do libraries seek to promote to staff as part of the library service concept?

2. Library staff as innovators:

2.1 What are the staff's attitudes and social norms that promote or prevent the adoption of e-books and related services (by staff of e-books) as part of a library service concept?

2.2 What organizational activities and educational features affect the adoption of ebooks and related services by the library's staff as a part of the library's service concept? 


\subsection{Data Collection}

The research data is primarily based on interviews. Six libraries were selected for the interviews from different parts of Finland. The libraries are operating as county libraries or are otherwise locally large libraries. The library executive boards were interviewed in a group interview as representative of their organization. Altogether six executive boards interviews were conducted with the average duration of one hour. In addition, five staff members from each library were interviewed, 30 persons in total. The average duration of the interviews was approximately 45 minutes. The interviews are anonymized in the analysis.

The research data also includes printed material: the library strategies or city's strategies have been used to determine the written values of the library. In addition, the national library strategies in Finland are used. There are references only to the national strategies in the text because the local strategies are also anonymized.

The interview questions of the attitudes and values were drawn up in accordance with the Davis Technology Acceptance Model, by studying the interviewees' perception of the usefulness and ease of use of the e-books, as well as exploring information acquisition and use of e-books.

\section{$4 \quad$ Findings and Results}

In the following we analyse the strategies and their adoption by the staff from the pointof-view of e-book use and services in the libraries.

\subsection{Values and Strategies}

In Finland, the operational functions of public libraries are guided by the Library Act and the national library strategy of Ministry of Education and Culture. The strategy of the Council for Public Libraries substantiates national strategy, and the regional and local library and information strategies provide national policies to the local level, considering specific needs of their own operating environment [9].

The core content of the strategies is based on the civic rights of the education and culture [10]. The values of the strategies are passed down from the upper level and complement the libraries' own values when local conditions are observed. In the strategies, values are named with different names, but their meanings are similar in all strategies. In Table 1, the values are combined based on similarities and their meanings are opened in different strategies.

The libraries researched use for executive functions the library's own strategy, city strategy, or city strategy formulated to the library. According to the analyzed strategies, the libraries' mission is very coherent: the library secures and provides culture, information, and learning opportunities to all. It encourages active nationality by strengthening literacy and narrowing the digital divide. The business idea is 
implemented by providing professional and equitable library and information services, considering customer needs.

Table 1. Values and their meanings in different strategies.

\begin{tabular}{|c|c|c|c|}
\hline Values & $\begin{array}{l}\text { Meaning in national } \\
\text { strategies }\end{array}$ & $\begin{array}{l}\text { Meaning in local } \\
\text { stategies }\end{array}$ & $\begin{array}{l}\text { Meaning in decision } \\
\text { makeing in libraries }\end{array}$ \\
\hline Equality & $\begin{array}{l}\text { Citizens' equal rights to } \\
\text { education despite the } \\
\text { place of residence }\end{array}$ & $\begin{array}{l}\text { Library operations } \\
\text { must be equal for all } \\
\text { customers }\end{array}$ & $\begin{array}{l}\text { Equal opportunities } \\
\text { for digital content }\end{array}$ \\
\hline Relialibility & $\begin{array}{l}\text { Reliable and up-to-date } \\
\text { content }\end{array}$ & $\begin{array}{l}\text { Professionally } \\
\text { selected and trusted } \\
\text { collection }\end{array}$ & \\
\hline Communality & $\begin{array}{l}\text { Library supports the } \\
\text { development of civic } \\
\text { skills }\end{array}$ & $\begin{array}{l}\text { Encourage active } \\
\text { citizenship by } \\
\text { strengthening } \\
\text { literacy and } \\
\text { narrowing the } \\
\text { digital divide }\end{array}$ & $\begin{array}{l}\text { Preventing digital } \\
\text { exclusion }\end{array}$ \\
\hline $\begin{array}{l}\text { Open- } \\
\text { mindedness }\end{array}$ & $\begin{array}{l}\text { Introduction of new } \\
\text { content and services }\end{array}$ & $\begin{array}{l}\text { The development of } \\
\text { operations must be } \\
\text { creative and bold }\end{array}$ & $\begin{array}{l}\text { Libraries are up to } \\
\text { date and offer up-to- } \\
\text { date services }\end{array}$ \\
\hline $\begin{array}{l}\text { Customer } \\
\text { orientation }\end{array}$ & $\begin{array}{l}\text { Services and operating } \\
\text { culture based on customer } \\
\text { needs }\end{array}$ & $\begin{array}{l}\text { Customers involved } \\
\text { in the design and } \\
\text { development of } \\
\text { services }\end{array}$ & $\begin{array}{l}\text { Identify and provide } \\
\text { material in the form } \\
\text { required by the } \\
\text { customer }\end{array}$ \\
\hline Availability & Versatile collections & $\begin{array}{l}\text { Versatile and } \\
\text { multilingual content }\end{array}$ & $\begin{array}{l}\text { Expand the collection } \\
\text { in print and in e-book }\end{array}$ \\
\hline Accessibility & $\begin{array}{l}\text { High quality services and } \\
\text { collections }\end{array}$ & $\begin{array}{l}\text { Multi-channel } \\
\text { service production } \\
\text { for different user } \\
\text { groups }\end{array}$ & $\begin{array}{l}24 / 7 \text { online Services } \\
\text { takes disabled into } \\
\text { account }\end{array}$ \\
\hline $\begin{array}{l}\text { Skill/compete } \\
\text { nces }\end{array}$ & $\begin{array}{l}\text { Adequate skills in } \\
\text { technology and } \\
\text { information management }\end{array}$ & $\begin{array}{l}\text { Expertise must be } \\
\text { versatile and fully } \\
\text { utilized }\end{array}$ & \\
\hline Challenges & $\begin{array}{l}\text { New content, self- } \\
\text { publishing } \\
\text { Local government and } \\
\text { economic }\end{array}$ & $\begin{array}{l}\text { Changes in } \\
\text { information } \\
\text { channels, material } \\
\text { formats and people's } \\
\text { time usage } \\
\text { Economic }\end{array}$ & $\begin{array}{l}\text { From logistics to } \\
\text { content }\end{array}$ \\
\hline
\end{tabular}

Libraries justify the introduction of e-book services by referencing national and local strategies. National strategies guide libraries to follow-up development, but the implementation of services is influenced by local strategies. However, the decision to 
introduce e-book services has not been made directly under the guidance of the strategy, but the strategies have opened the discussion of implementation.

The development of the activities aims to ensure that the library's services are up-todate. People's habits of searching and using information and literary culture are changing, and at the same time the communication of libraries must change into ways that serve those needs. Libraries should monitor and be involved in development and provide new formats to customers as soon as possible.

The core value of libraries is equality. Equality is aimed at providing equal opportunities for everyone to access digital content and thereby preventing digital exclusion. Equal opportunities for digital content are also aimed at promoting media literacy skills and teaching customers across the digital divide. Digitalization also aims to provide customers different ways to access library collections and to reach new user groups.

Libraries see customer orientations as an important value in introducing e-books. With customer orientation, one aims to provide all material equally to all customers and to identify what kind of material and in what form the customer needs the material at any given time. Ensuring customer orientation requires versatile material, both traditional and digital.

Libraries like that the fact that provision of e-books can promote availability. The availability in sparse-populated areas can be improved by providing e-book collection by remote access to customers' homes, and the use of library material is no longer dependent on library opening hours and distance. E-books can promote the accessibility of content to different customer groups, such as reading and mobility impairments. Ebooks also expand the collection and individual titles can be found in the collection both in print and in e-book.

The e-book is considered to be content in libraries rather than format. The purpose of the libraries is to provide content, and there is no need to emphasize the forms of content provided. The aim is to provide timely, versatile material and customers should be able to choose in which format they want material to be provided. Libraries should also provide customers access to material that is only provided in digital form. Digitalization also aims to guide the library's operations from the logistics to opening the content.

\subsection{The Actions of Libraries Implementing of the E-books to the Staff}

The strategies of the libraries raise staff competence and include the requirement that staff should be able to borrow and read e-books so they can teach the library patrons how to use them. It is not enough for the staff to know the technical basics of e-books; they also need to internalize the meaning of e-books in the provision of library services.

After the decision, staff have been informed and introduced to e-book services. Information has focused on informing customers about the service and its implementation. Various channels have been used for information purposes. The staff would want to be informed of the introduction of new services at the earliest possible stage of the change. About e-books, information is primarily sought from the 
information specialist, who is responsible for them, because their knowledge is more trusted than superiors'.

Staff have been provided with practical guidance in the use of e-books. Guidance has been given orally, in writing and some libraries have produced guidance videos for the use of e-books. The guides have been technical in content, showing how e-book services are used and how to borrow an e-book on different devices. Written instructions and videos are available to the staff on the intranet and to customers on the library's website. The same guidelines are aimed at both staff and customers.

Staff training on e-books and related services has been in-house training in the library. Typically, the information specialist, who is responsible for acquiring e-books is familiar with the services and their use, has prepared and trained the personnel of the library. The training sessions are arranged either centrally at the main library or the information specialist has traveled to the branch libraries to teach their staff. External training experts have not been used to train library personnel. One aim of the internal training has been to show the importance of service in library services.

Libraries have provided for information specialists and librarians responsible for customer guidance external training, as they have a greater need for professional development in digital media. Training for libraries has been outsourced by county libraries in cooperation with national library operators. External training at the regional level has been difficult to organize because not everyone has been able to participate due to long journeys and staff arrangements. Participation in training has been facilitated by streaming and recording training events (Library Chanel). Streaming has provided remote attending, recording and public sharing of recordings familiarizing with the training when it is best suited to work. Recordings have also been used in the library's internal training.

Some of the libraries under investigation operate a so-called "digi-janitor". They are ICT students who are in the library as interns and organize learning sessions as a digital cafe. Their tasks include teaching the use of information technology to the library staff and customers. Typical subjects to be taught are the use of tablets and smartphones, as well as the use of the library's digital services, including e-book services. This has been proven to be a good way to train the staff, but some libraries have also been found it problematic. The staff does not feel the development of their own competence is important if they can transfer the job requiring competence to someone else. Outsourcing is also seen as the library underrating one of its own core services, staff training in the library's own services.

During the deployment phase of the e-book service, staff have been required to take part in training and, as the implementation progresses, to independently access the services and borrow and read e-books. Libraries have also acquired suitable equipment for reading e-books, mainly tablets, so that staff can get acquainted with them. Independent study and peer support has been challenged because the interviewees considered their own knowledge and experience of e-books as weak, making it difficult for them to rely on information from other colleagues.

In the deployment phase of e-book services, e-book services and their use were generally discussed at staff meetings. Subsequently, the topic has only been dealt with if there are changes in the services that customers must be informed of. E-books have 
been discussed at meetings if there are problems, such as breaks in service, or criticisms have been raised by staff or customers. The staff have found that e-books are not discussed at a general level in meetings, such as issues arising from other duties.

In the informal discussions, e-books are raised as a topic only if there is a need to find solutions to the problems or if there have been changes in the services. Also, discussions with colleagues about e-books are not considered as reliable as discussion about other work issues. Information from a colleague regarding e-books is reviewed by the instructions or by another colleague and attitudes towards colleagues' knowledge of e-books are more critical than other work assignments. Some of the interviewees reported that they trust more information about e-books from their friends than colleagues. Actions are shown in table 2 .

Table 2. Actions for implementing e-book service.

\begin{tabular}{|c|c|c|c|c|}
\hline Actions & Content & Channel & Realizer & Object \\
\hline Informing & $\begin{array}{l}\text { What is an e-book } \\
\text { What is eLibrary } \\
\text { Schedule and } \\
\text { steps for } \\
\text { implementation }\end{array}$ & $\begin{array}{l}\text { Intranet } \\
\text { eMail } \\
\text { Superior } \\
\text { meetings } \\
\text { Staff meetings }\end{array}$ & $\begin{array}{l}\text { Information } \\
\text { specialist } \\
\text { Spokesperson }\end{array}$ & Staff \\
\hline Instructions & $\begin{array}{l}\text { How to borrow } \\
\text { and read e-Book }\end{array}$ & $\begin{array}{l}\text { Person } \\
\text { channel } \\
\text { Writings } \\
\text { instructions } \\
\text { Guide videos }\end{array}$ & $\begin{array}{l}\text { Information } \\
\text { specialist } \\
\text { ICT-Librarians }\end{array}$ & $\begin{array}{l}\text { Staff } \\
\text { Customers }\end{array}$ \\
\hline $\begin{array}{l}\text { In-house } \\
\text { training }\end{array}$ & $\begin{array}{l}\text { How to use } \\
\text { eLibrary }\end{array}$ & $\begin{array}{l}\text { Main library } \\
\text { Branch } \\
\text { libraries }\end{array}$ & $\begin{array}{l}\text { Information } \\
\text { specialist }\end{array}$ & Staff \\
\hline $\begin{array}{l}\text { External } \\
\text { training }\end{array}$ & $\begin{array}{l}\text { E-book in library } \\
\text { collections, } \\
\text { aquicitions and } \\
\text { lisencing } \\
\text { Technology issues }\end{array}$ & Seminars & $\begin{array}{l}\text { County libraries } \\
\text { Libraries.fi } \\
\text { Consortium of } \\
\text { Public Libraries } \\
\text { Regional State } \\
\text { Administrative } \\
\text { Agency }\end{array}$ & $\begin{array}{l}\text { Information } \\
\text { specialist } \\
\text { ICT- } \\
\text { Librarians }\end{array}$ \\
\hline $\begin{array}{l}\text { Peer support } \\
\text { and self- } \\
\text { study }\end{array}$ & $\begin{array}{ll}\text { Technical know- } \\
\text { how } & \\
\text { Problems } & \\
\end{array}$ & $\begin{array}{l}\text { Branch } \\
\text { libraries }\end{array}$ & Staff & Staff \\
\hline "Digi-janitor" & $\begin{array}{ll}\text { Technical know- } \\
\text { how } \\
\text { Problems }\end{array}$ & $\begin{array}{l}\text { Branch } \\
\text { libraries }\end{array}$ & ICT Students & $\begin{array}{l}\text { Staff } \\
\text { Customers }\end{array}$ \\
\hline
\end{tabular}

\subsection{The Attitudes of Library Staff Towards E-books}

Library staff feel that e-books and related services are part of the library's service offering. However, e-book services are considered as complementary and 
supplementary services in the library. They are not seen as the core task of the library. As a supplementary service, e-books are perceived as a very small part of the overall collections and they do not often come up as a topic in customer service situations. Some of the staff have also experienced e-books as threats, as they feel that most customers want to borrow and read a printed book and at the beginning were afraid that e-books would replace printed literature.

Library staff attitudes towards e-book are generated from practical work. The interviewees raise the benefits of the e-book through the e-book's activities. According to staff, customers benefit from e-books because they can be borrowed while traveling and are more convenient to carry with them than a printed book. They also said that the queues for e-books are shorter than the printed book, meaning that the customer gets to borrow an e-book faster than a printed one. E-books are also good for readers with reading disabilities, as it can zoom font size, and e-book services also offer audio books. On the other hand, the issues raised in staff interviews are those commonly used by the e-book marketing in different media. E-book benefits to customers are also viewed as greater for non-fiction and staff feel that students benefit most from e-books. Some staff feel that customers do not read fiction in e-books at all.

\section{$5 \quad$ Discussion and Limitations}

The decision of libraries to implement e-book services is based on the strategy of libraries. Library staff are expected to accept e-book services as a part of the library's service palette. However, there is a gap between the expectations of the library management and the staff. The library staff understand and accept e-books as part of the services and collections, but connection with the library's values and strategies seems not to be internalized, and thus their importance in the implementation of strategies is not understood. From this point-of-view, the adoption of an e-book service remains superficial and no real strategic diffusion happens from the management level to the actions of the staff.

Learning in the workplace and information literacy are formed from several external and internal sources and by people who work together [4]. In libraries, the staff are trained in the introduction of e-book services from the point of view of their technical characteristics, but the ideology and strategic goals of e-books in the library's mission have not been clearly discussed with the staff. The gap between the objectives of the library and the staff's adoption of the services arises when the strategic goals are left to the staff's own learning.

Business matters are discussed both in informal discussions and formal meetings. The fewer the staff meetings, the more that informal discussions matter. The importance of team and staff meetings about e-books is emphasized especially when informal discussion about them does not happen. In lobby conversations, the problem arises from the validity of the information received from a colleague. This also emerged in a study by Crawford \& Irving [5] where they found that people's resources in the workplace are essential, but the evaluation of colleagues' data's reliability has an effect how it is 
interpreted. An assessment of the reliability of the data is done on the basis of the colleague's knowledge and experience [5]. Thus, even reliable information can be rejected [11].

There are several factors in creating information needs and affecting what is really happening: the organization's goals and needs are central here [5]. In this study, this did not happen because the strategies were not well-known among the staff. According to Crawford \& Irving [5] there may be external drivers, which may generate a need to validate the organization's activities against these objective measures. In this study, external factors pass the poorly understood library strategy, for instance, general discussion about e-books in different media.

Internalizing e-book services for the staff requires formal discussions in the libraries. Information filtering and evaluation through the organization's strategy and values should be seen as part of information literacy in the workplace. The valid implementation of the strategy requires extra effort by the management.

The limitations of this study are that this study addresses only attitudes and values towards e-books and how they affect the adoption of innovation. Nonetheless, the results highlight the same factors as information literacy based on work tasks. Future studies should include how information literacy in the work-place affects adoption and implemention of e-books as an innovation.

\section{References}

1. Rogers, E. M.: Diffusion of Innovations. 5.ed. Free Press, New York, (2003)

2. Davis, F. D., "Perceived usefulness, perceived ease of use, and user acceptance of information technology", MIS Quarterly, 13 (3): 319-340 (1989)

3. Erwin, Phil: Attitudes and persuasion. Psychology Press, Hove (2001)

4. Lloyd, Annemaree: Trapped between a Rock and a Hard Place: What Counts as Information Literacy in the Workplace and How Is It Conceptualized? Library trends fall 277-296 (2011)

5. Crawford, John and Irving, Christine: Information literacy in the workplace: A qualitative exploratory study. Journal of Librarianship and Information Science, 41 (1) March 29-38 (2009).

6. Knuuttila, S.: Kaiken kattava kulttuuri. Kulttuurintutkimus, Editors: Jari Kupiainen \& Erkki Sevänen. P. 9-31. 3.ed. Suomalaisen Kirjallisuuden Seura, Helsinki (1994)

7. Aharony, N.: Librarians' attitudes towards mobile services. Aslib Proceedings, 65 (4) 358 $375(2013)$

8. Molopyane, Jeannet and Fourie, Ina: A framework for workplace information literacy in academic contexts Central University of Technology, Free State (South Africa) as case study. Library Hi Tech, 33 (4 ) 562 - 583 (2015)

9. Opetusministeriön kirjastopolitiikka 2015 Yleiset kirjastot. Kansalliset strategiset painoalueet. Opetusministeriön julkaisuja 2009:32. Opetusministeriö, Helsinki, 2009

10. Yleisten kirjastojen neuvoston strategia 2011-2016 (2010). http://www2.kirjastot.fi/File/aca26e87-aleb-4925-8c560491d5751bcf/Ykn-strategia-kirjastoversio-fin.pdf

11. CILIP (2012). Information literacy skills. https://www.cilip.org.uk/cilip/advocacy-campaignsawards/advocacy-campaigns/information-literacy/informationliteracy 